\title{
建築の空間構成を記述する形式言語（生成文法）の可能性 IDEA OF ARCHITECTURAL FORMAL LANGUAGE USING DYCK LANGUAGE
}

\author{
服部岑生* \\ Mineki HATTORI
}

\begin{abstract}
Here is proposed that architectural design can be described and explained by some kind of formal language, because of the unique character that the design is composed of elementary space units. I study the origins of this type of idea refering documents on modern architectural theories and research reports (Western and Japanease), investigate what kind of formal language is best applicable and propose a newly developped system using Dyck languge.
\end{abstract}

Keywords : architectural Design, space organization, formal language, dyck language, modern architecture, accessibility 建築設計，空間構成，形式言語，ダイク言語，現代建築

\section{1.はじめに}

本研究は, 形式言語の理論におけるアルファベットの 記号列から形成される語が，例えば，2 DKなどのよう に記号化された建築空間と類似していることに着眼し， 形式言語学の蓄積を用いて, 形式言語としての建築空間 の記号化の可能性を探ったもっである。

「記号化」の言葉には，人工的に都合のよい記号の当 てはめ方を考案するというニュアンスがあるが,ここは， 建築空間の常識的な理解の前提になっている事柄を踏ま え，空間の建築計画的な基本特性を明らかにするという 記号化を行う。ここでいう建築計画的な特性とは，建築 の空間構成の多様なイメージのうち，人間が一般的に体 験する, 現代建築の固有の, 空間単位から形成される空 間構成（後述）をいう。

\section{2. 研究の位置づけ}

建築のような三次元の物体を記号化する方法は, Stiny (1978), Mitchell (1990) や Flemming (1987) 等により研究されてきた。これらは建築の図面における 図形の文法一一形態文法 Shape Grammar ${ }^{1}$ ——考案 し; 建築の図面を描く形態操作の手続きをアルファベッ 卜などの記号で示している。しかし $2 \mathrm{DK}$ のうな記号 化 (モノイド2) とは, (1)記号列が図形操作の手続きを 示すもので, (2)建築の空間構成そのものの記号化でない 点で異なっている。その他, 表面的に似ている形式言語 に, 図形記述言語（川野，1984など）があるが,これ
も二次元平面上の図形を記述する手続きを示すものであ るし，記号化による語モノイドを意識していない。 本研究は，2DKのように記号化された建築の空間構 成およびその方法が，住戸などの空間構成を簡明に記号 化でき，一般に流布した点を評価して構想された，新し い類型の研究である。これまで, 空間構成の記述は, グ ラフ理論における隣接行列（Steadman，1983に多数紹 介がある) の方法や形態文法 (Shape Grammer) など があった。前者は，隣接関係を厳密に記述するが $2 \mathrm{DK}$ の簡明さはない。後者は, 空間構成そのものを記述しな い。そこで, 比較的, 元の空間の布置関係のイメージを 保存しながら記述する可能性がある語モノイドに着目し た。また，モノイドによる記号化では，形式言語の研究 成果である生成文法 ${ }^{3)}$ を適用でき, 建築の空間構成の原 理的な事項を明らかにすることができると考えた。

この結果, 建築の記号化であるモノイドおよびその生 成文法の適用範囲は, まず一般に建築を語る際や建築計 画の分野で空間構成の分析（特に黒沢，1988のような 分析）を行うなどの際に有効である。もちろん，CAD などで建築図の作成や空間構成の自動化・最適化などの 技術に対しても，その応用が考えられるが既往の研究開 発とは異なるものとなろう。

\section{3. 前提になる概念}

この研究における，基本的な概念を述べる。 


\section{（1）建築の空間構成}

ここでいう建築は，常識的な意味であり，その内部の 空間の単位の, 種類およびその相互関係を, 空間構成と する。建築の空間構成の理解の方法は, 規模, 距離関係, 隣接, 用途・行動上の意味など無数にあるが, 本研究で は，以下の上うに限定して考える。

建築の空間構成 (A と略記) は, 一般に室や通路と される空間単位とそれらを連結する連結関係のシステム (後述)で定められるとする(理由は後述する)。さらに， 何を空間単位とするかについては，一定の制約（後述） があるが，必要に応じ決めてよいとする。連結関係は， 動線のように，交通の可能性（扉・ドアなどによる直接 の可能性，通路による間接の可能性の両者を含む）を持 つ連結関係を代表的な例とする関係であるが，これも必 要に応じ，決めてよいとする。

\section{（2）形式言語（または語，文）}

代数学では，アルファベットのような記号の単位を連 接してできる記号列を，モノイドあるいは自由モノイド としている。その意味で，例えば $2 \mathrm{DK}$ のように記号化 された建築は，モノイドに置き換えられたといえる。モ ノイドに関する形式言語は，例えば，与えられた単位元 のアルファベット $\Sigma$ 上の形式言語とは， $\Sigma^{* 4)}$ の語の任 意の部分集合であると定義される。まずここで，形式言 語理論で生成系の定義) (生成文法) の仕方として知ら れる, chomsky の句構造文法 ${ }^{5)}$ の記述法を用いて, 最初 は断定的であるが，次の文法と要素による，文脈自由句 構造文法による形式言語を考案する。

文法 $\mathrm{G}=(\Sigma, \mathrm{V}, \mathrm{A}, \mathrm{P})$

ただし， $\Sigma$ : 終端記号一室 $1 \mathrm{~s}_{1}$, 室 $2 \mathrm{~s}_{2}$, 通路 $1 \mathrm{c}_{1}, \times$ インエントランス $e_{1}$ 等, の具体の空間単 位の集合および，括弧 $(,),,[$,$] の記号$ $\mathrm{V}$ : 非終端記号一 $\mathrm{A}$ や，必要に応じ設定され る他の終端記号の部分集合をまとめて示す 総称記号

\section{$\mathrm{A}:$ 公理一建築の空間構成 \\ $\mathrm{P}:$ 生成規則 (後述)}

提案の内容は, 後に詳しく説明する。

今, 例示として $2 \mathrm{DK} や 3 \mathrm{LDK}$ などの言語の規則を 求め, 文法の意味を明確にする。この集合住宅の住戸の 平面形を表現する記号列は，まず，終端記号である，一 般居室の部屋数 $1,2,3,4 \cdots$, 居間あるいは居間スペー ス $\mathrm{L}$ ，食事室あるいは食事スペース $\mathrm{D}$ ，台所あるいは 調理スペース Kの三種類の部屋から成り立つ。

$$
\Sigma: \mathrm{n}(2,3,4,5 \text { など), L, D, K }
$$

次に非終端記号は, 部屋数の総称 $\mathrm{N}$, 部屋の総称 $\mathrm{R}$ である。

$$
\mathrm{V}: \mathrm{N}, \mathrm{R}
$$

$2 \mathrm{DK}$ などを理解する常識的な道筋に沿った生成規則
$\mathrm{P}$ を作る。まず，(1)住戸の部屋数を明らかにする。 $\mathrm{A} \rightarrow$ $\mathrm{NA}$, 部屋数の具体化として, $\mathrm{NA} \rightarrow \mathrm{nA}$ と導出される (以 下同様)。次に,(2)居間の有無を明らかにする。nA $\rightarrow \mathrm{nRA}$,

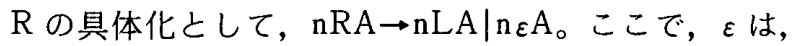
居間などの検討中の部屋がないことを示す空記号であ る。また， （は左辺の記号が, 右辺の記号へ変換され, 新たな記号を生成・導出することを示し，|は，その変 換による生成の際に, 複数の種類の変換が起こりうる場 合を表現する，区切りを示すものである。さらに，(3)食 事室の有無を明らかにする。 $\mathrm{n} * \mathrm{~A} \rightarrow \mathrm{n} * \mathrm{RA}, \mathrm{R}$ の具体 化として, nLRA $\rightarrow \mathrm{nLDA} \mid \mathrm{nL} \varepsilon \mathrm{A}$ あるいは $\mathrm{n}_{\varepsilon} \mathrm{RA} \rightarrow$ $\mathrm{n}_{\varepsilon} \mathrm{DA} \mid \mathrm{n}_{\varepsilon \varepsilon} \mathrm{A}$ 。これらは, まとめて $\mathrm{n} * \mathrm{~A} \rightarrow \mathrm{n} * \mathrm{RA}, \mathrm{n} *$ $\mathrm{RA} \rightarrow \mathrm{n} * \mathrm{DA} \mid \mathrm{n} * \varepsilon \mathrm{A}$ とすることができる。ここで,*は, なんらかの終端記号のアルファベットが存在しているこ とを示す。同様に, (4) $\mathrm{n} * * \mathrm{~A} \rightarrow \mathrm{n} * * \mathrm{RA}, \mathrm{n} * * \mathrm{RA} \rightarrow$ $\mathrm{n} * * \mathrm{~K} \mid \mathrm{n} * * \varepsilon$ 。以上である。

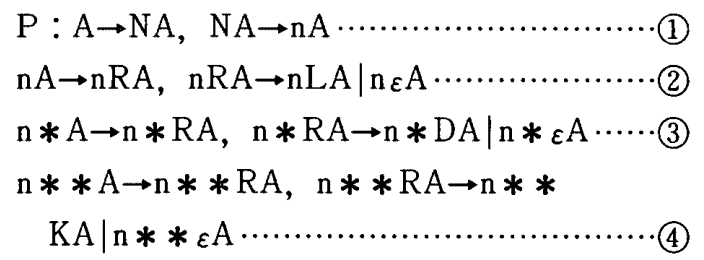

ここで(5)，生成規則の終了を意味する規則である。 $\varepsilon$ は, 単位元で実際には省略してよい。

以上の規則は，この言語が生み出すすべての空間構成 の原理となる。ここで, (1)から(5の規則が順に適応され るプロセスは，あたかも設計の際に空間構成のイメージ が具体化していくことに類似しており, 生成文法の性質 が空間構成を記号化するのに向いていることが予想され る。また，適切な原理による文法が得られれば，それか ら生成されるあるゆる空間構成が記述できたことになる ことも注目すべき性質であろう。

\section{(3) 記録の方式}

形式言語は, アルファベットを連接して形成される 語6)の集合であり，それを記録する方式（線状，上下左 右の二次元方向, 分子模型のような三次元方向など）に よって記録に馴染みやすい対象之馴染みにくい対象が出 てくる(後述)。本研究では, 簡明な記号化のために線 状に記録することとする。線状の方式では,アルファベッ トの単位元は英文のように線状に連接する。このために， グラフの木（ツリー）構造》で示されるアルファベット の連接に適している(後述)。

\section{4. 生成規則の基盤としての建築計画論の概観}

ここでは, 形式言語の対象とする空間構成の考え方に ついて，その歴史的な背景について考察する。原 （1967-p. 146）の「近代建築思想の基底に構成主義が ある……構成なる概念は要素を集合することを意味する 
のだから, 要素の役割と全体性の分析が当然なされてし かるべきなのだ。とする考えでは, 建築の空間構成の 基本的な特徵は,「要素から構成される」点に見出され ている。近代建築とそこから展開した現代の建築が, 要 素の集合による構成主義を基本にしているとする考え は, Banham (石原訳, p.18〜) によると, Guadet (1902) の「建築のエレメントと理論」が,「建築物の構成をそ の諸要素と全体性において研究することにある。そして それは，建築物の規定のプログラムへの適合，および素 材の必然性への適合という二重の観点からなされる。」 として, 要素からの構成を主張したのを塙矢とし, Guadet の弟子であったA．ペレーとT.ガルニエ，さ らにコルビュジエ, ミースやグロピウスと伝達・継承さ れたという。その意味で, Guadet が様式的な設計論か ら機能的な空間の合理的設計論への展開を示し，「要素 から構成される」現代の建築論を導いたことは, 納得の 行くものである。しかし，Guadetの「要素」は，必ず しも人の体験できる内部を有する空間ではなかった。こ のような文字どおり内部を持つ空間が要素として意図さ れるのは，デ・スティルの主張の中に初めて見られ8), ギーディオン ${ }^{9)}$, 特にZ Zevi ${ }^{10)}$ の「空間としての建築」の 見方で一般化している。この二十世紀半ばの段階の空間 の考え方こそ, 現代の空間の内包である。確かに，空間 構成を, 人間の体験できる内部を持つ, 空間の要素の集 合として理解し,特徴を見出すことは, 現代の建築にとっ てはきわめて自然のことである。

さらに議論を進めると, 空間構成の把握については, 設計方法的な立場で見るのと，事後の解釈的な立場で見 るのとでは，大きく異なる。

Guadet や原の指摘は, 設計方法的な立場のものに属 するであろうが,「要素から構成される」方法という表 現で，すべての建築設計の方法を言い切るとなると，翼 論がでてくる。古くから「空間を分割していくやり方と 空間を結び合わせる方法の二つがある。」(菊竹 1955) と考えられてきた。これは，「分割と連結」と対比的に 言われる方法である。分割は，最初に空間の全体を指定 し, その内部を分割し, 複数の空間単位の構成を得てい く方法である。この際, 和風住宅の分割線が, 建具など の可動で通行可能な間仕切りになっているような前提を 置くことで，次の連結の方法との差異が明確になる。連 結は, 最初に空間単位を指定し, 適切な通行可能な通路 などで連結関係を持つように構成する方法である。その 意味で, 要素相互が初めから通行可能な境界で接触して いるかどうかは保証されていない。すなわち分割では， 全体の形態が定形に納められ，単位に制約がでることが ある。一方, 連結では, 単位の自由が得られるかわりに, 全体の形態は定形に納められにくくなることがある。

その他に，設計方法の考え方のアルゴリズムを比較的
明確に示している電算機による設計方法の基礎研究の分 野で, Whitehead (1974) が,「Improvement Techniques」 と対比する「Construction Techniques」は,「連結」に よる方法である。また, Steadman（1983-p.157）は, 平面形の数理的な形成方法の特性として, 「Constructive character」と「Selective character」があるとしている。 前者は, 必ずしも部屋のような要素だけではないが, 空 間を構成する要素を組み合わせて, 設計条件との適合を 模索していく方法を示しており, 後者は分割図 ${ }^{11)}$ の辞書 から，設計条件に適合した平面形を選択していく方法を 示している。すなわち, はじめに, 必要な空間要素の連 結関係を抽象的に表現するグラフを描いておき，あらか じめ全体のシルエットごとに用意されたすべての分割図 と照合し，対応する空間構成を当てはめる方法である。 前者は, 要素からの構成という現代建築の特色を継承し ているし, 後者も, 通行などの体験できる内部のある空 間単位の連結から, 空間構成を求めるという現代建築の 本質を示している。

以上の設計方法からの空間構成の論点は, 要素とそれ らが形成する全体との関係についてを焦点としている。 内容を対比的に整理すれば，いずれも空間単位は所与で あるが，ひとつの極は全体を所与とする構成論であり， 他の極は全体が所与でない構成論である。しかし，どち らの立場の構成であろうと, 空間の単位があり，はじめ に指定されるかどうかは別にして，全体も存在する。だ から次に述へる事後の解釈の立場からは，両者の区別は なくなってしまう。

次に，形成される建築空間を解釈する立場から，空間 構成についてみると, まず建築計画研究の見方が問題と なろう。日本の建築計画の理念の先駆者である長倉 (1934, p. 584～585) は, 間取りの決定の手続きで, 先ず「所要の室」を求め, それらについて配置するとす る中で,「通り抜け式の間取り」と「奇道式の間取り」 を区別している。この認識は，日本の伝統的な和室の空 間構成と廊下式の近代建築の構成の違いを指摘してい る。また，西山（1936，p.6)）は，約半世紀前に「建 築を室と建築組織線との二要素の結合として」考えるこ とを主張している。これらは, 単位となる室を要素にす るとする近代建築の命題を, 一歩進めて動線（西山の建 築組織線) の重要性を意識したもので, 本研究の考え方 に通じるものである。

空間構成は; 空間単位がなんらかの論理で関係づけら れ，秩序を持ち成立したものである。特に現代建築の流 れの中では; 空間は, 人間側の体験, 特に通行一動線一 という点から構成の手がかりを得てきた。以上の考察を 踏まえ, 本研究の形式言語は, 設計方法の立場からの「要 素亡全体の関係」と, 建築計画研究の「動線による構成」 のふたつの認識を条件として, 研究する。 


\section{5. 生成規則の条件づくり}

生成規則の条件について，(1) 一般言語に做い, 記述 の対象条件を整理し，その内の連結関係について，(2) 歩行などで通行可能な関係に絞り，空間単位の連結関係 の種類を明らかにする。さらに，(3) 記述の上でくふう を要する点を明らかにする。最後に，(4) 生成規則の条 件となる文脈規定性について，考察する。

\section{（1）記述の対象条件}

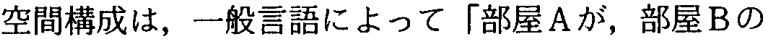
前にある」, 「部屋 $\mathrm{A}$ と B は, 廊下Cで繁がっている」, 「部 屋 $\mathrm{A}$ から, 部屋 $\mathrm{B}$ へ行ける」, 「建築は, 部屋 $\mathrm{A}$ と部屋 $\mathrm{B}$ で形成される」のように記述される。ここには，部屋の 種類や単純な位置関係，通行可能な連結の関係なよ゙が表 現されている。

一般言語において, 空間構成は，主体としての物，場 所 (あるいは位置)，および関係一例では，物相互の位 置関係一によって記述される。「場所」は，指示される 主体と，他の主体との相対的な関係によって，記述され

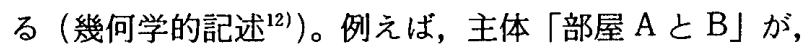
他の主体「廊下 C」によって，その存在する「場所」を， 暗示的に与えられている。この場合，「場所」は，単な る場所でなく「耧がって」いるという「関係」を前提 にすることで，特幑付けられている。

本研究では，建築の空間構成を i ）「空間単位」とii） 「場所」之iii）「通行可能な連結の相互関係」を条件とし て記述する方法を考案しようとするものである。一般言 語における空間記述と対比させると，この際のi）「空 間の単位」が，主体としての物であり，ii）「場所」が 他の物で暗示される場所で，iii）「通行可能性」が，ど のような関係性を持つかに対応している。

\section{(2) 空間単位の連結関係}

建築の空間単位を，通行の可能な他の空間単位の数に よって, i ) 一つの空間単位と通行可能な単位, ii)二 以上の単位と通行可能な単位の種類に分けて考える。

i ）の空間単位は，他の一つの空間単位へ移動できる 出入口しか持たない状態である。この連結関係は, 建築 の空間の状態として, 最も単純なものであるので「基本 連結」(図一1のA) とし，その状態にある空間単位を「基 本連結単位」と名付ける。これに対して, ii ) の状態は, 個々には基本連結である二つ以上 $\mathrm{n} の$ 単位がひとつの 空間単位に連結されているので,「群連結」(図一1の B-1）または「 $\mathrm{n}$ 群連結」とし, その空間単位を「群連 結単位」または「n群連結単位」と名付ける。ii）は i ) に対して, 通行可能な単位 $(n-1)$ 個を加えた状態に ある(図一 1$)$ 。

既往の建築の空間構成を, 生成規則による導出の結果 とみると，そこには基本連結や群連結以外に，図一1の B-2 のような, 基本連結が順に $\mathrm{n}$ 回連続して行かれる

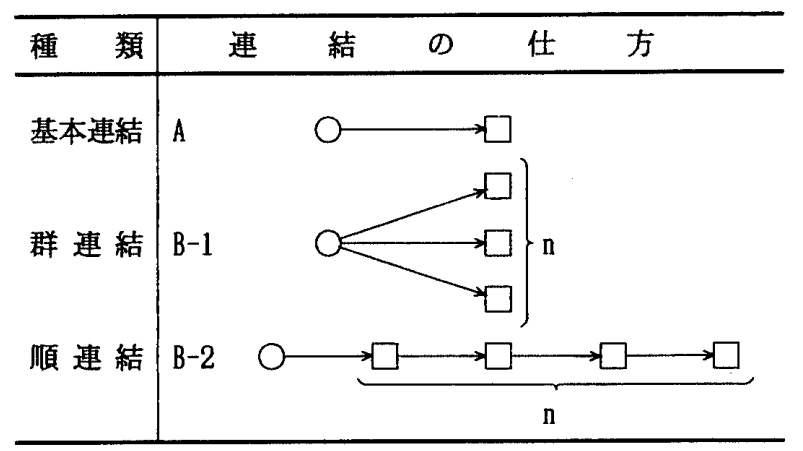

○、口; 単位空間、 $\longrightarrow ;$; 連結の存在あるいは生成 图一1＼cjkstart連結関係の類型

と得られると解釈できる連結が見られる。この連結を「順 連結」あるいは「順連結」と名付ける。また，群連結 は，基本連結の生成を，繰り返しひとつの空間単位に加 えると得られると解积される。以上の生成は，グラフ理 論における木構造の導出といえる。ここで, 基本連結・ 群連結および順連結の連結関係を, 総称して「線状の連 結関係」と定義する。この「線状」は，これら連結の共 通の特徵から名付けている。

（3）ループ状連結やブロックなどの扱い

空間単位については，空間構成の定義に示したように 常識的な内容でよいが，線状にモノイドを記録するため に，空間単位の決め方にくふうを要する。伝統的な建築 の空間単位の連結関係 (図一2) や, 空間単位を分割し て詳細にすると顕在化する連結関係——例えば，図一4 の通路は全体でひとつの単位空間とせずに複数の通路部

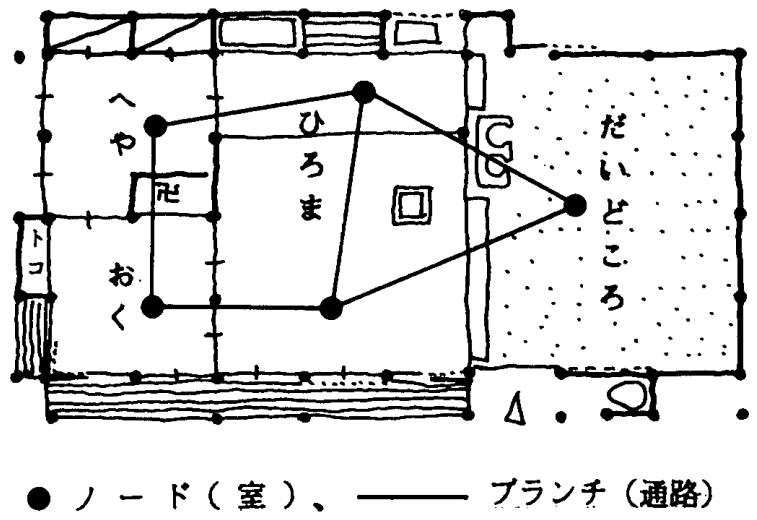

図一2 複数の部屋によるループ状連結関係（旧北村家平面図）

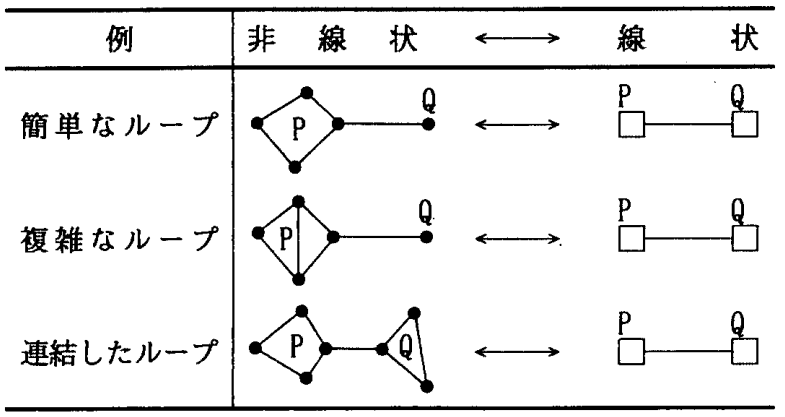

図一3 線状・非線状の対応関係 

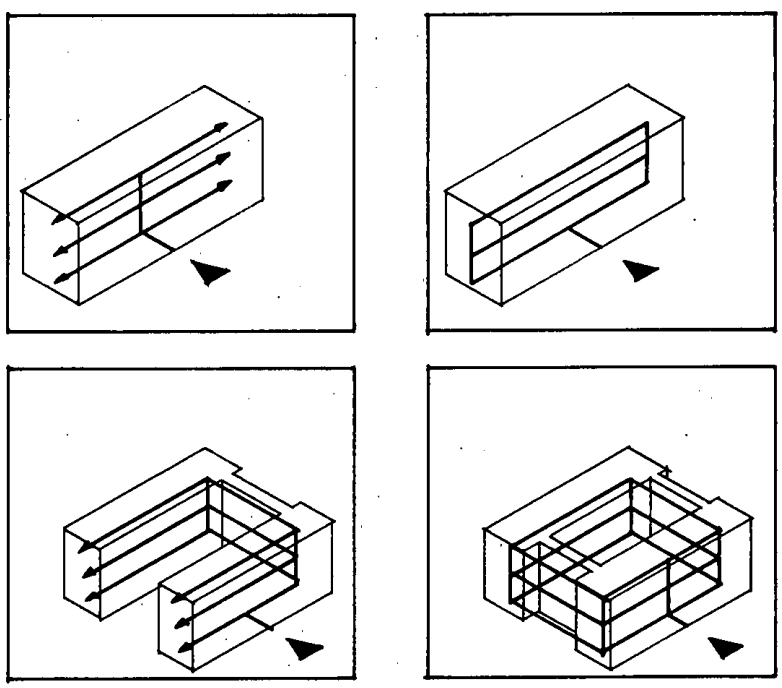

図一4 小学校に見られる通路のパターン (三次元のループがみられる)

分に分解して見ると複数の空間単位とその連絡関係が生 まれる—には，線状でないものがある。このような非 線状に連結している複数の空間単位は, 線状になる範囲 で複数をまとめ新たにひとつの空間単位を形成し記号化 する。すなわち、ループ状の連結関係などでは，個々の 空間単位が線状に布置されていないので,ループを構成 する空間単位をまとめて，ひとつの空間単位とするくふ うである。またこの操作は, 連結関係を木構造にするも のといえる(図一 3 参照)。

次に, 空間単位の分割の逆の問題である, 複数の空間 単位のまとまり，すなわちブロックの概念について，扱 いを考察する。建築計画の基本的な考え方として，個々 の空間単位の個性を一般化していきながら, 同種類, 同 系利用者の複数の空間をブロックやゾーンとしてまとめ る発想 (武田, 1925, Marcks, 1911 13),14) ) がある。こ の際のブロックの概念は，建築計画の概念として一般的 なものであり重要なものである。そこで，提案される形 式言語では, ブロックの記述の可能性を探ることとした。 また,ブロックについては, 建築の全体を, 複数のブロッ クに置き換えると, 部屋のレベルの空間構成と同様に, ブロックのレベルの空間構成が形成される。そこで，こ のブロックを新たに空間単位とすれば，ブロック相互に 基本連結・順連結や群連結の関係を見出すことができ る。

\section{（4）文脈規定性の扱い}

建築の空間構成について, 常識的に解釈すれば, 空間 単位となる部屋や通路には, 用途などの意味があり，そ の連結関係には建築の用途などから定まる，一定の条件 がある。例えば，玄関には，通路や居間が連結するなど の, 常識的に理解できる条件である。ここから, 空間単 位を導出する生成規則は，文脈規定を前提にしたものと なることが予想される。Chomskyによれば，文脈規定4)
とは，生成過程にある記号の置かれている環境に基づい て，書き換えが行われることをいう。例えば，玄関まで 導出されている記号の次の導出は, 基本連結となる通路 あるいは居間に限定される。玄関 $\rightarrow$ 玄関・居間というょ うに。しかし，本研究での空間単位は自由に設定される としており, 形式言語の最初の提案段階であるので, 文 脈規定の特性の組込みは行われないことにする。

\section{Dyck 言語（括弧を含む文脈自由言語 $)^{(5)}$ による記述 の妥当性}

様々な形式言語が提案されている。ここでは，始めに 標準的な文脈自由言語で正規表現(16)の方法と, 次に同種 で個性的な Dyck 言語による記述を試み, 後者の Dyck 言語の妥当性を確認するが,この段階では, 単に記述方 法を検討するに過ぎない。次の生成規則の作成の段階で, 本質的な検討を行う。

(1) 記述の具体化

いずれも，個々の空間単位に対応するアルファベット や常用される数式記号一 ( , ), 十など一によって記号化 する。

まず, 空間単位は, 建築の空間構成として, 常識的に あるいは必要に応じて区別される単位が明示的に区別さ れればよい。例えば, 居間を $\mathrm{s}_{1}$, 寝室を $\mathrm{s}_{2}$ のように単 位を示す終端記号 $\mathrm{s}$ とラベル（下付添数字）によって区 別することができ机ばよく，空間構成の考え方で自由に 設定してよい。

次に場所は, 建築の空間構成に現れる単位の, 連結関 係を記述することで，暗示的に相互の場所を示し，それ 以上の具体化は検討しない。

最後に, 通行可能等, 単位の連結関係, 関連するふた つの空間単位を, 連結の種類に対応する記号を間に置き 並べて記述する—例えば, 連結の記号十を使って, L +Dのように記述する—ことで示すこととする。三 以上の空間が同時に連結の関係を持つことがあり, 後に 示すようにくふうを要するが, 並べて記述するという考 え方は同じである。

（2）括弧を用いない正規表現 ${ }^{16}$ による検討

今, 入口 $\mathrm{e}_{1}$, 室 $1 \mathrm{~s}_{11}$, 室 $2 \mathrm{~s}_{12}$, 室 $3 \mathrm{~s}_{21}$, 室 $4 \mathrm{~s}_{22}$, 通
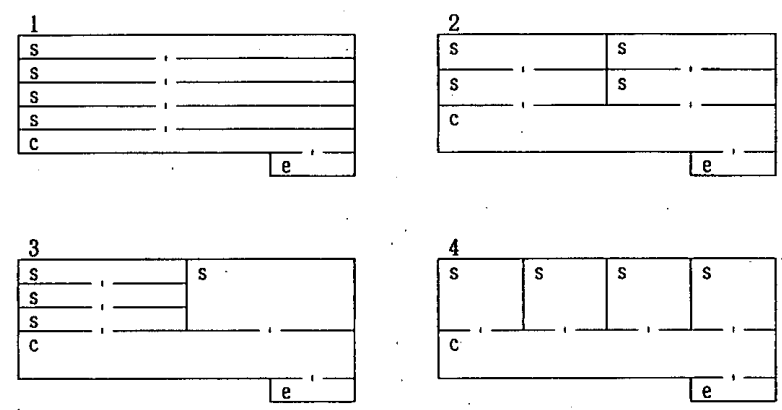

図一5 ケーススタデ.イーのための空間構成 
路 $\mathrm{c}_{1}$ の図一5-4 のダイアグラムで示されるような平面 (各空間単位の添字は，各々を区別するために適宜つけ た）を，考える。様々な記述法が考えられる。 ここで，記述項目を考える。

i ) 単位の区別 $\mathrm{s}_{11}, \mathrm{~s}_{12}, \mathrm{~s}_{21}, \mathrm{~s}_{22}$ の記号化

ii）基本連結・順連結や群連結の関係 $\mathrm{e}_{1}$ と $\mathrm{c}_{1}$ の関係, $c_{1}$ と $\mathrm{s}_{11}, \mathrm{~s}_{12}, \mathrm{~s}_{21}, \mathrm{~s}_{22}$ の関係等

iii) ブロック $\mathrm{s}_{11}$ と $\mathrm{s}_{12}$ のまとまり, $\mathrm{s}_{21}$ と $\mathrm{s}_{22}$ のまとまり

を，記述しなけ枕ばなない。正規表現の条件に基づき， 順連結や群連結を，記号の連接で表せば，最も簡単な表 現として， $e_{1}, c_{1}, s_{11} s_{12} s_{21} s_{22}$ のような, 体験的に納得で きるものが得られる。しかし，この空間単位の連接だけ では, 単位の相互関係, 通路 $c_{1}$ が四つの室の動線になっ ている順連結や群連結の関係, およびブロックの関係が, 自明でない。各空間単位の相互関係については，順連結 の場合は，隣あった記号の関係を基本連結の状態にある とすれば単純な連接で記述できるが, 群連結の関係は, 平等の連結関係を表す+などの区切り記号を利用——例 えば $\mathrm{s}_{11}+\mathrm{s}_{12}+\mathrm{s}_{21}+\mathrm{s}_{22}$ —し, 部屋のまとまりを示すこ とはできるが,これと動線 $\mathrm{c}_{1}$ との連結を同時に記述で きない。

\section{（３）括弧による記述}

群連結の関係とブロックを扱うには，記号の連接に対 して, i ) 連接に直接関連しないラベルを用いる方法と, ii）記号の連接に別のルールを与えて，ラベルを用いな い方法がある。

ラベルによる方法は, 表現が複雑になるが, 例えば室 $1 \mathrm{~s}_{11}$, 室 $2 \mathrm{~s}_{12}$, 室 $3 \mathrm{~s}_{21}$, 室 $4 \mathrm{~s}_{22}$ のように, 空間単位の

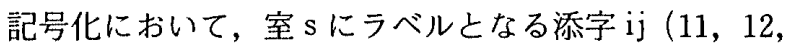
21 など）を添えて，ブロックの関係をiで暗示的に表 現するものである。

記号の連接に別のルールを与える方法は，正規表現を 諦めて一一括弧の利用が制限され，入れ子の構造表現が できない一, 空間単位以外に特殊記号の括弧を用意し て，群連結およびブロックの関係を明示的に表現するも のである。このような言語は，いろいろ提案されている が，ここでは形式言語一Dyck 言語15)適用し，ラベル は用いないこととする。

先に問題となった群連結とブロックの記述の問題は, 括弧を，i）連結の領域を表示すること，およびii）順 連結や群連結の関係にある動線や室のグループ，あるい はブロックを表示することの，二つに用いるような， Dyck 言語であれば，目的の記述項目を扱うことができ る。例えば， $\mathrm{e}_{1} \mathrm{c}_{1}\left({ }^{1} \mathrm{~s}_{11} \mathrm{~s}_{12} \mathrm{~s}_{21} \mathrm{~s}_{22}\right)^{\prime}$ のように，括弧（）を 用いればよい。括弧は，さらに詳細なブロックの関係， 例えばブロック 1一室 1, 室 2一とブロック 2一室 3 と室
4一を区別することにも， $\mathrm{e}_{1} \mathrm{c}_{1}\left({ }^{1}\left({ }^{11} \mathrm{~s}_{11} \mathrm{~s}_{12}\right)^{11}\left({ }^{12} \mathrm{~s}_{21} \mathrm{~s}_{22}\right)^{12}\right)^{1}$ のよ うに用いることができる。括弧によって，記号の連接を 区切り, 群連結とその連結の関係の範囲を記述すること が可能になる（図一5-4）。

\section{Dyck 言語による生成文法の試み}

\section{(1) 建築空間の記号化のイメージ}

最終的に，得られる記述結果の語を，以下に予告的に 示す。まず，主体として，記述する観察者の初めの視点 となる空間単位の記述を置き，そこに連結する，次は多 くは通路の空間単位を続ける。さらに通路の空間単位に 視点を移し，それを主体に，そこに連結する空間単位を 記述する。途中で，連結やブロックの範囲を区切る括弧 を入れる。以下同様に進め，一連の記述が完了してでき る記号の連接を語とする。なお, 各空間単位の区別を示 す添字は, 簡単のために省略してある。以下に, 語の例 を示す。

$\left.(\mathrm{e})(\mathrm{c}) \mathrm{K}_{1}[\mathrm{~s}][\mathrm{s}][\mathrm{s}][\mathrm{s}]\right)_{1}$

$(\mathrm{e})\left({ }_{1}\left[{ }_{2}(\mathrm{e})(\mathrm{c}) \mathcal{X}_{3}[\mathrm{~s}][\mathrm{s}][\mathrm{s}]\right)_{3}\right]_{2}\left[{ }_{4}(\mathrm{e})(\mathrm{c})(\mathrm{c})\right.$

$\left.\left.\left({ }_{5}[\mathrm{~s}][\mathrm{s}][\mathrm{s}]\right)_{5}\right]_{4}\right)_{1}$

この例のうち特に, (2)の語では, 文脈自由言語の「構 文上の多義性 ${ }^{177}$ を示している。連接する括弧の間の関 係が,「順連結」,「群連結」および「ブロックのまとまり」 のいずれを記述しているか明確でないからである。これ を避けるために，順連結を示す丸括弧（，）と，群連結 を示すかぎ括弧［］を使い分けている(後述)。

\section{(2) 括弧の使い方}

括弧を以下のように使い分ける。Dyck 言語は，括弧 の入れ子構造を記述するものであるが,ここでは単位元 の括弧を区別するラベルを，括弧の中の空間単位の名前 $\mathrm{s}$ によって代替し，括弧のラベルを取ることにしている。 これによって，括弧のみで記述される Dyck 言語が，空 間構成を実感的に表現するものになったと考えた。

i ）空間単位の列挙の際の区切りを示す …...ラベル無し括弧 $(,),,[$,

ii）連結の範囲とブロックの始めを示す ……ラベル付左括弧（，[など 連結の範囲とブロックの終わりを示す ……ラベル付右括弧），] など ただし，ラベル（下付添字）は括弧の種類を示す。 （3）生成規則による文法の基本構造 語の終端記号の集合として,

$$
\left.\Sigma=\left\{\left(l_{1},\right)_{1}, l_{2},\right)_{2}, \cdots \cdots \cdot(\mathrm{n},)_{n},(,)\right\}
$$$$
\cup\left\{s_{1} \mid 1 \leqq i \leqq m\right\}
$$

空間構成としての, 唯一の非終端記号, $\mathrm{V}=\{\mathrm{A}\}$

生成規則として,

$\mathrm{P}=\mid) \mathrm{A} \rightarrow \mid \varepsilon\}$ 


$$
\begin{aligned}
& \left.\left.\cup\{)_{1} A \rightarrow\right)_{i}, \varepsilon \mid 1 \leqq i \leqq n\right\} \\
& \cup\left\{A \rightarrow\left({ }_{1} A\right)_{1} A \mid 1 \leqq i \leqq n\right\} \\
& \cup\left\{\left({ }_{1} A\right)_{1} \rightarrow\left(s_{1}\right) \mid 1 \leqq i \leqq m\right\}
\end{aligned}
$$

文法のシステムとして,

$\mathrm{G}=(\Sigma, \mathrm{V}, \mathrm{A}, \mathrm{P})$

この規則は, Dyck 言語の基本の規則を, 一部変形し たもの一一特に，(5)，(6)左括弧を前提にした A の単位 元 $\varepsilon へ$ へ変換; (8)の空間単位の記号 $\mathrm{s}$ を残す規則の追加 一である。その意味では, 純粋の Dyck 言語ではない が, 先に述べた(3)の $\mathrm{s}$ の意味と定義を, 元に戻せば Dyck 言語になるので, n 次の疑似 Dyck 言語といって よい。

(3)は，終端記号，すなわち括弧と空間単位の記号の集 合である。. (4)は, 非終端記号で, 建築の空間構成 Aを示 す。(5)一 (8)までは生成規則で，(5)は導出を終わる時に， 非終端記号を単位元へ変換する, あるいは表記しないよ うにする規則, (6)も同様だがその左の括弧がラベル付の 規則, (7)はDyck 言語に基本的な括弧を導出する規則, (8)は括弧内の A を終端記号 $\mathrm{s}$ ，すなわち具体の空間単位 の記号に変化する規則である。(9は, 以上の(3)から(8)ま でが, 文法の要素であることを示している。

しかし，このままでは順連結之群連結の区別が明快で なく構文上の多義性 (1)を解消するくふうがない。そこで, 順連結に対する括弧と群連結に対する括弧を区別し，そ れぞれ（，）と［，］とにする。これによって，多義性 は解消する。

また, 非終端記号 $\mathrm{A}$ を, 建築の空間構成において, 特 徵的な出入口 $\mathrm{e}$, 通路 c, 部屋 $\mathrm{s}$ などを区別するように, 例えば $\mathrm{A} \rightarrow \mathrm{e}, \mathrm{A} \rightarrow \mathrm{c}$ や $\mathrm{A} \rightarrow \mathrm{s}$ のように具体的なイメージ が沸くルールを付け加え，展開することもできる。そう すると，建築の典型的な空間単位に個別に終端記号を用 意するくふうとなる。ここで, $A \rightarrow \mathrm{e}_{1}\left|c_{\mathbf{i}}\right| s_{\mathbf{i}}$ の規則を用い, 連続して記号の導出を行う際, 出入口 $\mathrm{e}$, 通路 $\mathrm{c}$, 部屋 $\mathrm{s}$ の意味を考えると, 常識的な連接の条件が出てきて, 文脈規定性を考慮しなければならないが，この段階では 配慮しないこととする。以下に, 終端記号 $\Sigma$ と生成規 則 $P$ を変更した文法の具体化を示す。

$$
\begin{aligned}
& \Sigma=\left\{\left(\left(_{1},\right)_{1},\left(_{2},\right)_{2}, \cdots \cdots\left(_{n 1},\right)_{n 1},(,)\right\}\right. \\
& \cup\left\{[1,]_{1},\left[{ }_{2},\right]_{2}, \cdots \ldots\left[n_{n},\right]_{n_{2}},(,)\right\} \\
& \cup\left\{e_{1} \mid 1 \leqq i \leqq m_{1}\right\} \\
& U\left\{c_{i} \mid 1 \leqq i \leqq m_{2}\right\} \\
& \cup\left\{s_{1} \mid 1 \leqq i \leqq m_{3}\right\} \\
& \mathrm{P}=\{) \mathrm{A} \rightarrow) \varepsilon\} \cup\{\} \mathrm{A} \rightarrow] \varepsilon\} \\
& \left.\left.\cup\{)_{1} A \rightarrow\right)_{1} \varepsilon \mid 1 \leqq i \leqq n_{1}\right\} \\
& \left.\cup\{]_{i} A \rightarrow\right]_{i} \varepsilon\left|1 \leqq i \leqq n_{2}\right| \cdots \\
& \cup\left\{A \rightarrow\left({ }_{1} A\right)_{1} A \mid 1 \leqq i \leqq n_{1}\right\} \text {. } \\
& \cup\left\{A \rightarrow\left[{ }_{1} A\right]_{i} A \mid 1 \leqq i \leqq n_{2}\right\} \\
& \cup\left\{\left({ }_{i} A\right)_{1} \rightarrow\left(e_{j}\right) \mid\right.
\end{aligned}
$$

$\left.\left.1 \leqq i \leqq n_{1}, \quad r \leqq j \leqq m_{1}\right\} \cdots \cdots \cdots \cdots \ldots \ldots \ldots \ldots . . .16\right)$

$U\left\{[i, A]_{1} \rightarrow\left[e_{i}\right] \mid\right.$

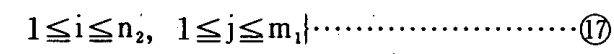

$\cup\left\{\left(c_{1} A\right)_{1} \rightarrow\left(c_{j}\right) \mid\right.$

$1 \leqq i \leqq n_{1}, 1 \leqq j \leqq m_{2}$

$\cup\left\{\left[\mathrm{i}_{1} \mathrm{~A}\right]_{1} \rightarrow\left[\mathrm{c}_{\mathrm{i}}\right] \mid\right.$

$1 \leqq i \leqq n_{2}, \quad 1 \leqq j \leqq m_{2} \mid$

$\cup\left|\left({ }_{1} A\right)_{1} \rightarrow\left(s_{1}\right)\right|$

$1 \leqq \mathrm{i} \leqq \mathrm{n}_{1}, 1 \leqq \mathrm{j} \leqq \mathrm{m}_{3} \mid$

$\cup\left\{\left[{ }_{1} A\right]_{1} \rightarrow\left[s_{1}\right]\right\}$

$1 \leqq i \leqq n_{2}, 1 \leqq j \leqq m_{3} \mid$

ここで， $m_{i}, n_{1}$ の記号および添数字は, それぞれ引用 される終端記号等の種数を示すもので, 適切に定められ るものとする。先の文法との関係は，容易に類推できる

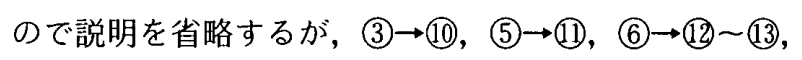

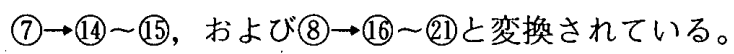

前記の(1)よび(2)の例示は，この文法に基づき記述し た語であり，構文上の多義性はない。しかし，ここでは， ( , ) と [, ] の連続関係には, 一定の文脈規定を考虑 しなければならない。すなわち， $\varepsilon ，($,$) と [$,$] のす$ べての組み合わせで，非論理的な連結を避ける必要があ る。Dyck 言語自身が生成しない（]などの組み合わせ を除き，次の連結が問題である。

i ) …...) $[\cdots \cdots \cdot$ の連結

ii ) $\cdots \cdots .].(\cdots \cdots \cdot$ の連結

iii) $\cdots \cdots \cdot[[\cdots \cdots \cdot$. 連結

iv) $\cdots \cdots \varepsilon[\cdots \cdots \cdot$ の連結

例えば，i）は，ブロックや単位の終わりを示す括弧） に順連結の関係の始まり（を連接することはできるが, 群連結の関係の始まりを示す [を連結できない。群連結 単位を連接する場合は，一端ブロックの始まりを示す （を置き，続けて [を連接すればよい。以下ii〜iv）は， 説明を省略するが, 同様に常識的に考えられないもので ある。これらを，生成規則としてまとめる。

$$
\begin{aligned}
& \text { U \{) } \left.A \rightarrow)\left({ }_{1} A\right)_{1} A \mid 1 \leqq i \leqq n_{1}\right\} \ldots \ldots \ldots \ldots \ldots \ldots \ldots \ldots . . .22 \\
& \left.U\{] A \rightarrow][1, A]_{1} A \mid 1 \leqq i \leqq n_{2}\right\} \ldots \ldots \ldots \ldots \ldots \ldots \ldots . . .23
\end{aligned}
$$

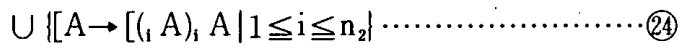

$$
\begin{aligned}
& U\left\{\varepsilon A \rightarrow\left({ }_{1} A\right)_{1} A \mid 1 \leqq i \leqq n_{1}\right\} \cdots \ldots \ldots \ldots \ldots \ldots \ldots \ldots . . .(25)
\end{aligned}
$$

そこで, (14)を(22), (24)と(25), (15)を(23)に, 置き換えなけ ればならない。

ここで……((……連結を問題にしていないが, 記 述の結果が例えば $((((\mathrm{s}))))$ というような語となるこ とがあろうが,この多重の括弧の意味は常識的な空間構 成には対応するものがないであろう。しかし，ここでは， この欠点については, 意識されていたことを付記して今 後の課題としたい。

(4)記述のケーススタディ

記述の際, 観察者が最初に取る視点を, 建築の主入口 
にとり，空間構成を普通に記述する立場を，「静的」な 記述とし, 建物利用者が建築の内部の, 部屋や通路など, 主観的に必要な視点で記述を始める立場を,「動的」な 記述とする。この区別は，ここで記述される語が，一般 的な空間構成の表現になるかどうかであり，「静的」な 記述では建物は一つの語に写像されるが,「動的」な記 述は観察者の視点の数だけ，すなわち空間単位の数だけ ある。

\section{(a) 静的な記述}

既存の空間構成を，文字どおり記述する。まず図一 5-1において, エントランスに着目すると, $A \rightarrow(A)$

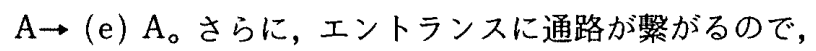

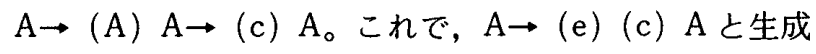
されている。通路に部屋が基本連結の関係で生成を繰返 し最終的に 4 室連結する。 $\mathrm{A} \rightarrow(\mathrm{A}) \mathrm{A} \rightarrow(\mathrm{A})$ (A) $\mathrm{A}$ $\rightarrow$ (A) (A) (A) A $\rightarrow$ (A) (A) (A) (A) A。すべて の部屋を具体的に入れると, $A \rightarrow(s)(s)(s)(s) A$ (簡 単のために添字を省略する, 以下同様)。単位元 $\varepsilon$ によ り $\mathrm{A} \rightarrow \varepsilon$ として記述を終える。最終的な, 記述結果は, $\mathrm{A} \rightarrow(\mathrm{e})(\mathrm{c})(\mathrm{s})(\mathrm{s})(\mathrm{s})(\mathrm{s})$ となる。

(b) 動的な記述

同様の空間構成を，例えば 4 部屋の奥から 2 番目の部 屋から記述する。

初めに, $\mathrm{A} \rightarrow(\mathrm{s}) \mathrm{A}$ を得る。次に, $\mathrm{A} \rightarrow(\mathrm{A}) \mathrm{A}$ とな

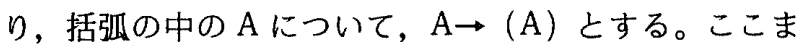
でで, 全体は $\mathrm{A} \rightarrow(\mathrm{s})$ ([A] A) A となる。さらに, 括 弧の中の左の $\mathrm{A}$ を具体化して $\mathrm{A} \rightarrow(\mathrm{s})\left({ }_{1}[\mathrm{~s}] \mathrm{A}\right), \mathrm{A}$ と する。括弧の中の残った $\mathrm{A}$ を $\mathrm{A} \rightarrow[\mathrm{A}] \mathrm{A} \rightarrow[(\mathrm{A}) \mathrm{A}]$ $A \rightarrow[(A)(A) A] A と し て, A \rightarrow[2 \text { (s) (s) A }]_{2} A$ を得る。さらに, 括弧 [ ] の中に残った $A$ を展開して, $\left.\mathrm{A} \rightarrow(\mathrm{s}) \quad(1 \mathrm{~s}][2(\mathrm{~s})(\mathrm{s})(\mathrm{c})(\mathrm{e})]_{2}\right)_{1}$ の最終の記述結 果を得る。

このように動的な記述は, 最初の視点によって, 静的 な記述と違い空間構成の意外なイメージを示すもので, グラフ理論などにない, 視点に対応した空間構成を記述 できる可能性を示唆している。

終わりに，この記述例で得られる注意と問題点を挙げ る。まず,ここで, 単位元の空間単位を示す括弧はラベ ルを持たないこと，ブロックを示す括弧はラベルを持つ ことに注意する。また， [2（s）（s）(c)（e)] 2 の記述に おいて，空間単位の ssce の連結関係は，（）と $[$, を区別しなければ記述の上では基本連結の生成の繰り返 しなのか, 群連結の関係の生成なのか区別できないとい う, いわゆる多義性が出てしまう。

（5）文法の課題と解決の考え方

これまでの議論から，ループ状の複数の空間単位は, まとめて線状の連結関係の空間単位にして, 扱うくふう を要する。しかし，このように記述にくふうを必要とす
る空間や特性は, 多数ある。和風住宅の空間構成 ${ }^{18)}$, あ るいは現代建築にしばしば見られるような複雑な空間構 成一一服部 (1979) は, 小学校建築において, 通路に二 次元 (a) および三次元 (b) でのループ状連続が大量 に存在していることを指摘している。(図-4参照, ダ イアグラムの辺は, 通路を簡略化して示している)は, その例である。また,この言語では, 他に多くの記 述されていない情報一例えば, 空間単位の形状や階数 など—があるし, 通行可能な空間単位は扱われるが他 に記述できない空間構成の情報一吹き抜けのような空 間, グリッドパターンなどのパターンなど—ーが多くあ る。これらの内,「要素と全体」の関係で捉えられる空 間構成の記述という，この形式言語の考え方に馿染まな い一例えばグリットパターン一一空間の特性は対象外 であるが，それ以外の制約は，提案の規則で空間単位の 列挙が可能になっているので, 空間単位に記号をあたえ る際に統一的なルールを持つラベルを付ければ解決す る。例えば，ループ状の空間単位の類型を網羅し，その 識別番号を空間のアルファベット記号にラベルとして加 えるような方法である。これによって，記述できなかっ た情報は，ほぼ記述できるようになる。

\section{8. まとめと考察}

\section{（1）形式言語の可能性}

巷間で常用される 2 LDK のような記号化が, 形式言 語の生成文法によって論理的に説明されること,および 現代建築の基本にある「要素による建築の構成」と「動 線による空間の理解」を前提に, 建筑の空間構成が Dyck 言語を応用した形式言語によって記述可能である ことを検証し，基本的に形式言語の可能性を明らかにす ることができた。この成果は, 既に研究の蓄積のある形 式言語の類型を, 建築空間を適用することで得られたも のであり, 本研究で限定した記述対象を前提にする場合 の基礎的な成果となったと考える。

現代建築の要素による構成の考え方を基礎にしたこと と記録を線状にしたことの制約があるが，空間単位や括 弧の記号に，他に必要な情報をラベルとして添えれば， ほぼすべての情報を記述する記号化の方法が得られたと いえる。

\section{(2) 今後の展望}

形式言語として, 建築空間を捉えることは, ルールを 勝手に設定するのでなく, 単位を記号化して空間の奏態 を記述する「基本言語」を, 科学的に一すなわち他分野 と共有する仕方で一構成しようとするものである。その 意味で, 得られた結果は, 記述にくふうを要する側面が あるが, 科学的, 論理的な構成を持つとともに, 簡明に 了解しうるものとなった。既に概観したように既往の関 連研究による図形記述言語の開発は, 電子計算機による 
作画等に応用されてきた。同様に，本研究の成果も，電 子計算機に関連する諸技術と共通の認識に基づき，空間 構成の数理的な処理一一統計処理, 類型化, 分割図のよ うな形態に関する辞書の作成等一一道を開くことにな るであろう。また，既往の研究においても応用分野となっ てきた，空間構成の分析に，文字に゙おりに空間構成を対 象にして，その生成規則を明らかにするような，これま でと若干異なった形で適応される可能性が考えられる。 Shape Grammar のように建築図の観点ではないし，グ ラフ理論等の応用による空間構成の自動化・最適化など の観点でもないが，総合的には，本研究も CAD などの 建築の空間構成の計画を導出するような技術への道に通 じているだろう。

注

1) Stiny (1978, p. 124) により命名されている。

2）単位元をもち，いたるところで結合的算法をもつ集合一 仮に $A$ とすると $A$ はモノイドと呼ばれる。そのなかでも， 連接の演'算一 $\mathrm{A}=$ ' 'bcac', $\mathrm{B}=$ ' ac'に対して $\mathrm{AB}=$ ' bcacac', $\mathrm{BA}=$ ' acbcac'のような演算一をもつ集合 $A^{* 2)}$ は, $A$ の上の自由モノイドになり，Aの要素はその生成 元と呼ばれる。 $A^{*}$ は, $A$ の生成元のすべての連接により 生まれる「べき集合」である。

3）生成系の定義法とは, 言語の記述において, Chomsky の 提案 ${ }^{5}$ したもので，言語が生成する記号あるいは文の全 体を，直接羅列・記述する事が不可能であるので，その 生成文法によって記述する考え方。

4）記号の集合 $\Sigma$ の積 $\Sigma \times \Sigma$ を $\Sigma^{2}$ のように表現すると $\Sigma^{*}$ $=\varepsilon \cup \Sigma \cup \Sigma^{2} \cup \Sigma^{3} \cup \Sigma^{4} \cup \Sigma^{5} \ldots . .$. である。クリーン演算, あるいは閉包演算という。

5）Chomsky によると有限終端記号, 有限非終端記号, 公理, 生成規則によって定義される文法（文 13，p. 83）で, 形 式言語の種類を分ける, 生成規則 $\alpha \rightarrow \beta$ の特徴は, 以下 のように分類される。

i ) $|\alpha| \leqq|\beta|$

ii) $\alpha \in V,|\beta| \geqq 1$

iii) $a \in \mathrm{V}, \beta \in \Sigma^{*} \cdot(\Sigma \cup \mathrm{V})$

ただし， $\alpha$ と $\beta$ は, 語であり, $\alpha, \beta \in(\mathrm{V} \cup \Sigma)^{*}, \mathrm{~V} \cap$ $\Sigma=\phi$

i）・のような，語が增殖しながら導出される規則は，文 脈規定文法である。ii）は，非終端記号からなんら規定 のない記号が生成される，文脈自由文法である。iii）は， 生成によって左に必ず終端記号が生まれるもので, 正規 文法とも呼ばれる。

6) 原則としてアルファベットにより, 大文字を総称記号 (集 合), 同じ文字の小文字をその具体的要素として表記する。 $=$, 括弧（）, 説明記号：，，，|などの意味は，代数 学の表記に従っている。他の特別の表記については, そ のつど説明される。

7) 木構造 (ツリー) は, 「A tree is a connected acyclic graph.」(F. Harary, 1969, p. 32)

8）デ・スティールの創始者のベルラーへは, 建築において 本質的なものは，装飾でなく，「空間創造とマスの関係」 （文 2, p. 203）と主張し, 後にG. リートフェルトらは,
より樻極的に空間の概念を発展させたという（同 p. 275）。

9）立体派の「対象の外観を有利な一点からでなくその内的 構成を把握」しようとした考え方を基本に，建築空間を 意味付けた。（文 4, p. 466）。

10）「二次元の空間を越えて，建築は，われわれに; われわれ 個人を内包することのできる三次元の空間を提供する」 (文 3 , pp. 248 249)

11）建築空間の抽象化されたモデルとして，矩形あるいは立 方体を定められた数の要素の矩形あるいは立方体に分割 する図。それを分割する数ごとに網羅したものを分割図 の辞書と呼ぶことがある。

12）一般言語に現れる空間的対象（物）の幾何学的な記述の こと。(文 15, pp. 75〜96)

13）武田は住宅を「接客用の諸室 (Guest Department), 家 族住居用の諸室 (Family Department) など」と分類し ている。(文 8, pp. 158 161)

14） Marcks のブロックの発想を示す記述「Grouping consisits in giving due proximity to parts intimately related.」(文 9, p. 125)

15) $\left.\Sigma_{\mathrm{n}}=\left\{\left(l_{1},\right)_{1},\left(_{2},\right)_{2}, \cdots \cdots()_{\mathrm{n}},\right)_{\mathrm{n}}\right\}$ $\mathrm{V}=\{\mathrm{S}\}$

$P_{n}=\{S \rightarrow \varepsilon\} \cup\left\{S \rightarrow\left({ }_{i} S\right), S|1 \leqq i \leqq n|\right.$

$G=\left(\Sigma_{n},|S|, S, P_{n}\right)$

で生成される言語。(文 10, p. 177〜)

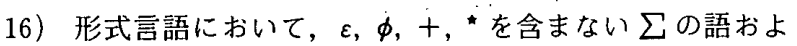
び $\varepsilon, \phi の$ 要素の和, 積および階乗 (十, “) で作られる 式を，正規表現という。(文 13，p.62）

17）文の解釈において，一義的に解釈できない性質

18）書院造りの和室のように複数の室を，いわゆる通路によ らず通り抜ける動線の場合, 室の連結が一次元の記録に 馴染まないことがある。

文 献

1）原 広司：建築に何が可能か，学芸出版社，1967

2) Banham R. : Theory and Design in the First Machine Age, Architectural Press, 1960, 第 1 次機械時代の理論 とデザイン, 鹿島出版会, 石原達二ほか訳, 1976

3）Zevi B. : Architecture as Space, 空間としての建築, 青銅社, 栗田 勇訳, 1975

4) Giedion S. : Space, Time and Architecture, 空間, 時間, 建築，丸善，太田 実訳，第三版，1962

5) Whitehead B. et al. : Three Dimensional Layout Planning, Building Science Vol.9, pp. 45 53, 1974

6) Steadman J. P. : Architectural Morphology, Pion Ltd, 1983

7）西山外三：建築計画における動線, 建築学研究 80, pp. 1 $\sim 15,1936.5$

8）武田伍一：住宅建築要義, 文献書院, 1925

9) Marcks P.L. : The Principles of Planning Buildings, B. T. Batsford, 1911

10) Cross $M$. et al : Notions sur les grammaires formelles, Gauthier-Villars Editeur, 1970, 数理言語学入門, 相沢 照昭ほか訳，東京図畫，1972

11）菊竹清訓：建築講座 6 計画, 彰国社, 新訂 1 版, pp. 44 $\sim 46,1971$

12）服部岑生 et al: : 千葉県の小学校の動線計画, 日本建築 
学会学術講演梗概集 (関東), 1979.4

13）福村晃夫 et al. : オートマトン・形式言語と計算墖, 岩 波講座情報科学 6 , 岩波畫店, 1982

14）渡㱛 要, 長倉謙介：計画原論, 高等建築学第 13 巻, 常 磐書房, 1934

15) Herskovits A. : Langage and spatial cognition, 1986, 空間認知之言語理解, 堂下修司ほか共訳, 才一ム社, 1992

16) Stiny G. et Gips J. : Algorithmic Aethetics, University of California Press, Berkely, 1978

17）川野 洋: コンピュータと美学, 東京大学出版会, 1984
18) Flemming $U$. : More than the sum of parts: the grammer of Qeen Anne houses, Environment and planning B, Vol. 4, pp. 323 350, 1987

19) Mitchell W.J. : The Logic of Architecture, MIT press 1990

20) Harary F. : Graph Theory, Addison-Wesley, 1969

21）黒沢和隆：動線条件から平面構成パターンを導く図法を 用いた住宅平面型のパターン分析手法, 日本建築学会計 画系論文報告集，第 392 号，pp. 41 51，1988.6

(1992 年 7 月 6 日原稿受理, 1992 年 12 月 24 日採用决定) 